Article

\title{
Synthesis of isosorbide-based polycarbonates via melt polycondensation catalyzed by quaternary ammonium ionic liquids
}

\author{
Wei Sun a,b, Fei Xu b, Weiguo Cheng b, Jian Sun b, Guoqing Ning a,\#, Suojiang Zhang b,* \\ a College of Chemistry and Chemical Engineering, China University of Petroleum-Beijing, Beijing 102249, China \\ ${ }^{\mathrm{b}}$ Key Laboratory of Green Process and Engineering, Beijing Key Laboratory of Ionic Liquids Clean Process, State Key Laboratory of Multiphase Complex \\ Systems, Institute of Process Engineering, Chinese Academy of Sciences, Beijing 100190, China
}

\section{A R T I C L E I N F O}

\section{Article history:}

Received 27 February 2017

Accepted 22 March 2017

Published 5 May 2017

\section{Keywords:}

Quaternary ammonium ionic liquid

catalyst

Isosorbide

Polycarbonate

Melt polycondensation

Aliphatic diol

\begin{abstract}
A B S T R A C T
A series of quaternary ammonium ionic liquids (ILs) were synthesized and employed as catalysts for the production of poly(isosorbide carbonate) (PIC) from diphenyl carbonate and isosorbide via a melt polycondensation process. The relationship between the anions of the ILs and the catalytic activities was investigated, and the readily-prepared IL tetraethylammonium imidazolate (TEAI) was found to exhibit the highest catalytic activity. After optimizing the reaction conditions, a PIC with a weight-average molecular weight $\left(M_{\mathrm{w}}\right)$ of $25600 \mathrm{~g} / \mathrm{mol}$ was obtained, in conjunction with an isosorbide conversion of $92 \%$. As a means of modifying the molecular flexibility and thermal properties of the PIC, poly(aliphatic diol-co-isosorbide carbonate)s (PAIC)s were successfully synthesized, again using TEAI, and polymers with $M_{\mathrm{w}}$ values ranging from 29000 to $112000 \mathrm{~g} / \mathrm{mol}$ were obtained. ${ }^{13} \mathrm{C}$ NMR analyses determined that the PAIC specimens had random microstructures, while differential scanning calorimetry demonstrated that each of the PAICs were amorphous and had glass transition temperatures ranging from 50 to $115^{\circ} \mathrm{C}$. Thermogravimetric analyses found $T_{\mathrm{d}-5 \%}$ values ranging from 316 to $332{ }^{\circ} \mathrm{C}$ for these polymers. Based on these data, it is evident that the incorporation of linear or cyclohexane-based diol repeating units changed the thermal properties of the PIC.
\end{abstract}

(C) 2017, Dalian Institute of Chemical Physics, Chinese Academy of Sciences. Published by Elsevier B.V. All rights reserved.

\section{Introduction}

Polycarbonate (PC) is an excellent engineering plastic widely used for various industrial applications owing to its unique properties, including high tensile strength, impact resistance, and good transparency [1,2]. Currently, one of the most important and widely commercialized PCs is bisphenol A PC (BPAPC) [3,4]. However, bisphenol A is a toxic, petroleum-derived chemical [5,6], and so much effort has been devot- ed to replacing this compound with bio-based monomers [7-9]. Isosorbide (1,4:3,6-dianhydro-D-sorbidol) is a well-known potential replacement and has the advantages of rigidity, chirality and low toxicity $[10,11]$. Moreover, it is the only carbohydrate-based bicyclic monomer currently commercially available [12] and so could represent an ideal renewable monomer for polymer synthesis [13]. To date, isosorbide has been widely used for the synthesis of polyesters [14-16], polyurethanes [17-19], poly(ester-co-carbonate)s [20,21] and PCs

\footnotetext{
* Corresponding author. Tel/Fax: +86-10-82627080; E-mail: sjzhang@home.ipe.ac.cn

\# Corresponding author. Fax: +86-10-69724721; E-mail: ngq@cup.edu.cn

This work was supported by the National Key Projects for Fundamental Research and Development of China (2016YFB0600903), the National Natural Science Foundation of China (91434107, 21506226, 21476245), and the Key Research Program of Frontier Sciences of Chinese Academy of Sciences (QYZDY-SSW-JSC011).

DOI: 10.1016/S1872-2067(17)62822-5 | http://www.sciencedirect.com/science/journal/18722067 | Chin. J. Catal., Vol. 38, No. 5, May 2017
} 
[22-26]. The large-scale production of poly(isosorbide carbonate) (PIC) via the melt polycondensation of isosorbide with dimethyl carbonate (DMC) or diphenyl carbonate (DPC) has also been investigated recently [5,27-29].

Isosorbide has some associated challenges such as its higher hydrophilic and lower acidity than that of bisphenol A, so the synthesis of PIC is complex [10]. The production of high molecular weight PIC requires suitable catalysts for the melt polycondensation process because of the severe reaction conditions. To date, basic catalysts have been found to be the most efficient for PIC synthesis [5,30,31]. Li et al. [29] synthesized a PIC by melt polycondensation of isosorbide with DMC, using lithium acetylacetonate as the catalyst. Shin et al. [5] reported that cesium carbonate exhibited superior catalytic activity during the synthesis of a PIC by melt polycondensation with DPC. Although inorganic bases have been used for this reaction $[32,33]$, they tend to have several drawbacks, including unsatisfactory activities, difficult separations and branching. More recently, basic ionic liquids (ILs) have been shown to be promising substitutes for inorganic bases [34-39]. As an example, Park et al. [40] demonstrated the transesterification of ethylene carbonate with methanol catalyzed by 1-alkyl-3- methylimidazolium ILs.

In recent years, many researchers have paid much attention to the functionalized ILs by designing the structures of cations or anions according to practical requirements and special purposes [41-46]. In the present work, we designed and synthesized several basic ILs and investigated the effects of the anions on the catalytic activities of these compounds during the synthesis of a PIC via the melt polycondensation of DPC with isosorbide. The results demonstrate that the readily synthesized IL tetrabutylammonium imidazolate (TEAI) shows the highest activity, producing a PIC with a weight-average molecular weight $\left(M_{\mathrm{w}}\right)$ of $25600 \mathrm{~g} / \mathrm{mol}$ in conjunction with an isosorbide conversion of $92 \%$. In addition, the molecular flexibility and thermal properties of the PIC were modified by synthesizing poly(aliphatic diol carbonate)s (PAIC)s through combining isosorbide and various aliphatic diols (diethylene glycol, 1,3-propanediol, 1,4-butanediol, 1,5-pentanediol, 1,6-hexanediol and 1,4-cyclohexanedimethanol). The PIC and PAICs samples were characterized by ${ }^{1} \mathrm{H}$ NMR and ${ }^{13} \mathrm{C}$ NMR spectroscopy, gel permeation chromatography (GPC), differential scanning calorimetry (DSC) and thermogravimetric analysis (TGA).

\section{Experimental}

\subsection{Materials and measurements}

Isosorbide (98\%) was purchased from Alfa Aesar, while 1,4-cyclohexanedimethanol (cis+trans, 99\%), 1,5-pentanediol (97\%), 1,6-hexanediol (98\%), 1,3-propanediol ( $\geq 99.5 \%)$, imidazole (99\%), 1,2,4-triazole (99\%), sodium dicyanamide (96\%), diethylene glycol (>99\%), tetramethylammonium hydroxide solution (TMAH, 25\% aqueous solution), tetraethylammonium hydroxide solution (TEAH, 25\% aqueous solution), tetrapropylammonium hydroxide solution (TPAH, 1.0 mol/L aqueous solution) and diphenyl carbonate (99\%) were purchased from Shanghai Aladdin Bio-chem Technology. The remaining reagents, 1,4-butanediol, silver nitrate, benzoic acid, tetrabutylammonium hydroxide solution (TBAH, $10 \%$ aqueous solution), acetic acid, lactic acid, isopropyl alcohol, dichloromethane, phosphorus oxide, sodium hydroxide and tetraethylammonium bromide, were purchased from Sinopharm Chemical Reagent.

${ }^{1} \mathrm{H}$ NMR spectra were recorded in deuterated water $\left(\mathrm{D}_{2} \mathrm{O}\right)$ or deuterated chloroform $\left(\mathrm{CDCl}_{3}\right)$ with tetramethylsilane (TMS) as the internal reference, using a Bruker Avance III-600 spectrometer. GPC was employed to estimate the $M_{\mathrm{w}}$ and polydispersity (PDI $=M_{\mathrm{w}} /$ number-average molecular weight $\left(M_{\mathrm{n}}\right)$ ), using an Agilent PL-GPC 50 system at $30^{\circ} \mathrm{C}$, with chloroform as the eluent $(1.0 \mathrm{~mL} / \mathrm{min})$ and generating a calibration curve with polystyrene standards. The glass transition temperature $\left(T_{\mathrm{g}}\right)$ of each polymer was determined by DSC using a DSC 1 instrument (Mettler Toledo) at a heating rate of $10^{\circ} \mathrm{C} / \mathrm{min}$ with a nitrogen gas purge $(50 \mathrm{~mL} / \mathrm{min})$. TGA data were acquired with a NETZSCH STA449F3 thermogravimetric analyzer under a nitrogen flow rate of $20 \mathrm{~mL} / \mathrm{min}$, heating samples (2.0-3.0 $\mathrm{mg}$ ) from 50 to $600{ }^{\circ} \mathrm{C}$ at a rate of $10{ }^{\circ} \mathrm{C} / \mathrm{min}$. Fourier transform infrared (FT-IR) spectra were recorded using a Thermo Nicolet 380 spectrophotometer.

\subsection{Synthesis of the quaternary ammonium IL catalysts}

The structures of the quaternary ammonium IL catalysts synthesized in this study are shown in Scheme 1, and the methods used to obtain these compounds are described below.

Tetraethylammonium imidazolate (TEAI) was prepared using a modification of a reported procedure [47]. Imidazole (0.68 g, $0.01 \mathrm{~mol})$ was added to a solution of $\mathrm{NaOH}(0.40 \mathrm{~g}, 0.01$ $\mathrm{mol})$ in isopropyl alcohol $(20 \mathrm{~mL})$ followed by refluxing for 30 min. Tetraethylammonium bromide ( $3.09 \mathrm{~g}, 0.01 \mathrm{~mol}$ ) was then added at room temperature and the resulting mixture was refluxed for a further $6 \mathrm{~h}$. The solid portion of the reaction mixture was removed by filtration, the solvent was evaporated under vacuum, and the residue (TEAI) was dried at $60{ }^{\circ} \mathrm{C}$ under vacuum over $2 \mathrm{~d}$. Yield: $1.87 \mathrm{~g}(95 \%)$; ${ }^{1} \mathrm{H}$ NMR (600 MHz, $\mathrm{D}_{2} \mathrm{O}$, $298 \mathrm{~K}): 7.62$ (s, 1H), 7.00 (d, 2H), 3.08-3.11 (q, 8H), 1.10-1.13 (m, 12H).

The synthetic method for tetraethylammonium 1,2,4-triazolate (TEAT) was the same as that used to obtain TEAI, except that 1,2,4-triazole $(0.69 \mathrm{~g}, 0.01 \mathrm{~mol})$ was added to the $\mathrm{NaOH}$ solution. Yield: $1.90 \mathrm{~g}(96 \%) ;{ }^{1} \mathrm{H}$ NMR (600 MHz, D $\left.{ }_{2} \mathrm{O}, 298 \mathrm{~K}\right)$ : 8.02 (s, 2H), 3.10-3.14 (q, 8H), 1.12-1.15 (m, 12H).<smiles>CCC(Cc1ncc[n-]1)N(CC)CC</smiles>

TEAI<smiles>CC[N+](CC)(CC)CCC(O)C(=O)[O-]</smiles>

$$
\text { TEAL }
$$<smiles>CC[N+](CC)(CC)CC</smiles>

TEAA

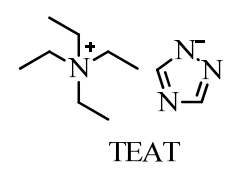

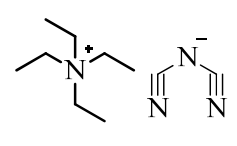

TEAD

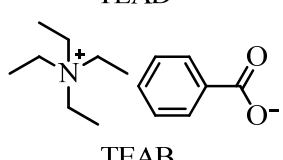

TEAB
Scheme 1. Structures of the quaternary ammonium ionic liquids synthesized in this work. 
Tetraethylammonium dicyanamide (TEAD) was synthesized according to reference [48]. A slight excess of freshly prepared silver dicyanamide $(1.90 \mathrm{~g}, 0.011 \mathrm{~mol}$, obtained by mixing aqueous solutions of sodium dicyanamide and silver nitrate, removing the resulting white solid by filtration and then washing with water) was added to an aqueous solution of tetraethylammonium benzoate (TEAB, $3.09 \mathrm{~g}, 0.01 \mathrm{~mol}$ ), after which the mixture was heated to $30-40{ }^{\circ} \mathrm{C}$ and stirred for approximately $1 \mathrm{~h}$. The solid precipitate (AgI and excess $\operatorname{AgN}(\mathrm{CN})_{2}$ ) was filtered off and the water was removed by rotary evaporation. The resulting material was dissolved in dichloromethane to precipitate a small quantity of silver dicyanamide, which was filtered off, following which the filtrate was evaporated to dryness. The TEAD was then dried under vacuum over $2 \mathrm{~d}$. Yield: 1.90 g (97\%); ${ }^{1} \mathrm{H}$ NMR (600 MHz, ${ }_{2} \mathrm{O}, 298 \mathrm{~K}$ ): 3.25-3.28 (q, $8 \mathrm{H}), 1.26-1.29(\mathrm{~m}, 12 \mathrm{H})$.

Tetraethylammonium lactate (TEAL) was synthesized by the acid-base neutralization method. Lactic acid $(0.90 \mathrm{~g}, 0.01$ mol) was added dropwise to a $100 \mathrm{~mL}$ single-necked flask containing TEAH ( $1.47 \mathrm{~g}, 0.01 \mathrm{~mol}$ ), after which the mixture was stirred for approximately $5 \mathrm{~h}$ at room temperature. Following this, water was removed by rotary evaporation and the sample was dried under vacuum for $2 \mathrm{~d}$. Yield: $2.10 \mathrm{~g} \mathrm{(96 \% );}{ }^{1} \mathrm{H}$ NMR (600 MHz, $298 \mathrm{~K})$ : 3.96-3.99 (q, 1H), 3.13-3.17 (q, 8H), 1.21-1.22 (d, 3H), 1.14-1.17 (m, 12H).

Tetraethylammonium acetate (TEAA) was obtained using the same method employed to synthesize TEAL, except that acetic acid ( $0.60 \mathrm{~g}, 0.01 \mathrm{~mol})$ was added. Yield: $1.80 \mathrm{~g}(95 \%) ;{ }^{1} \mathrm{H}$ NMR (600 MHz, $\left.\mathrm{D}_{2} \mathrm{O}, 298 \mathrm{~K}\right): 3.13-3.17$ (q, 8H), 1.80 (s, 3H), 1.14-1.17 (m, 12H).

The synthetic method for tetraethylammonium benzoate (TEAB) was the same as that for TEAL, except that benzoic acid (1.22 g, $0.01 \mathrm{~mol}$ ) was added. Yield: $2.41 \mathrm{~g}(96 \%) ;{ }^{1} \mathrm{H}$ NMR $(600$ $\left.\mathrm{MHz}, \mathrm{D}_{2} \mathrm{O}, 298 \mathrm{~K}\right): 7.79$ (d, 2H), $7.47(\mathrm{~m}, 1 \mathrm{H}), 7.40(\mathrm{~d}, 2 \mathrm{H})$, 3.09-3.13 (q, 8H), 1.12-1.15 (m, 12H).

\subsection{Synthesis of homopolycarbonates}

Isosorbide-based homopolycarbonates were synthesized by a one-pot melt polycondensation method, including transesterification and polycondensation (Scheme 2). A typical polymerization procedure (sample PIC-1) was performed as follows. Under a nitrogen atmosphere, isosorbide ( $4.38 \mathrm{~g}, 0.03 \mathrm{~mol})$ and DPC (6.43 g, $0.03 \mathrm{~mol}$ ) were transferred into a $250 \mathrm{~mL}$ three-necked round-bottom flask equipped with a mechanical
Table 1

Results obtained from the melt polycondensation of isosorbide and DPC using various catalysts.

\begin{tabular}{lcccc}
\hline Sample & Catalyst & $\begin{array}{c}\text { Conversion of } \\
\text { isosorbide }(\%)\end{array}$ & $\begin{array}{c}M_{\mathrm{w}}{ }^{\mathrm{a}} \\
(\mathrm{g} / \mathrm{mol})\end{array}$ & $M_{\mathrm{w}} / M_{\mathrm{n}}$ \\
\hline PIC-1 & TMAH & 94 & 17200 & 1.92 \\
PIC-2 & TEAH & 95 & 21300 & 1.98 \\
PIC-3 & TPAH & 92 & 22300 & 2.36 \\
PIC-4 & TBAH & 96 & 19700 & 1.94 \\
PIC-5 & TEAI & 93 & 23600 & 1.96 \\
PIC-6 & TEAD & 74 & 17500 & 2.08 \\
PIC-7 & TEAT & 92 & 19400 & 2.14 \\
PIC-8 & TEAB & 81 & 21800 & 2.33 \\
PIC-9 & TEAL & 77 & 15500 & 2.17 \\
PIC-10 & TEAA & 77 & 19600 & 2.09 \\
\hline Rea
\end{tabular}

Reaction conditions: isosorbide $(0.03 \mathrm{~mol})$, DPC $(0.03 \mathrm{~mol})$, catalyst $\left(1.50 \times 10^{-5} \mathrm{~mol}\right), 98^{\circ} \mathrm{C}, 5 \mathrm{~h}$ (first step), $230^{\circ} \mathrm{C}, 5 \mathrm{~h}$ (second step).

a Determined by GPC in chloroform $(1.0 \mathrm{~mL} / \mathrm{min})$ at $30^{\circ} \mathrm{C}$ with polystyrene standards.

stirrer, nitrogen inlet, reflux condenser, thermometer and feeding funnel. During the transesterification stage, the reaction mixture was heated to $98^{\circ} \mathrm{C}$, after which the catalyst TMAH $\left(0.014 \mathrm{~g}, 1.50 \times 10^{-5} \mathrm{~mol}\right)$ was injected into the flask and the mixture stirred continuously for $5 \mathrm{~h}$. The temperature was then gradually increased to $180{ }^{\circ} \mathrm{C}$, while the pressure was gradually reduced to $10 \mathrm{kPa}$ and maintained at this level for 10 min to completely remove the phenol byproduct as well as any unreacted DPC. In the polycondensation stage, a high vacuum (10 Pa) was applied and the temperature was gradually increased to $240^{\circ} \mathrm{C}$ and maintained at that level for $5 \mathrm{~h}$. The resulting polymer was dissolved in a minimal amount of chloroform and then precipitated by addition to methanol. The PC was recovered by filtration and dried at $80{ }^{\circ} \mathrm{C}$ under vacuum overnight. The PIC samples obtained by the melt polycondensation of isosorbide and DPC using the various catalysts are referred to herein as PIC-1 to PIC-10 as shown in Table 1. PIC-1, 1H NMR (600 MHz, CDCl 3 , 298 K): 3.89-4.06 (m, 4H), 4.50-4.54 $(\mathrm{m}, 1 \mathrm{H}), 4.87(\mathrm{t}, 1 \mathrm{H}), 5.06-5.09(\mathrm{~m}, 2 \mathrm{H}) ;{ }^{13} \mathrm{C}\left\{{ }^{1} \mathrm{H}\right\}$ NMR $(150$ $\left.\mathrm{MHz}, \mathrm{CDCl}_{3}, 298 \mathrm{~K}\right):$ 70.6, 73.1, 76.9, 81.0, 81.6, 85.8, 153.3, 153.6, 154.0.

\subsection{Synthesis of copolycarbonates}

The copolycarbonates of isosorbide and various aliphatic diols were also synthesized using a one-pot melt polycondensation method (Scheme 3). A typical copolymerization proce-

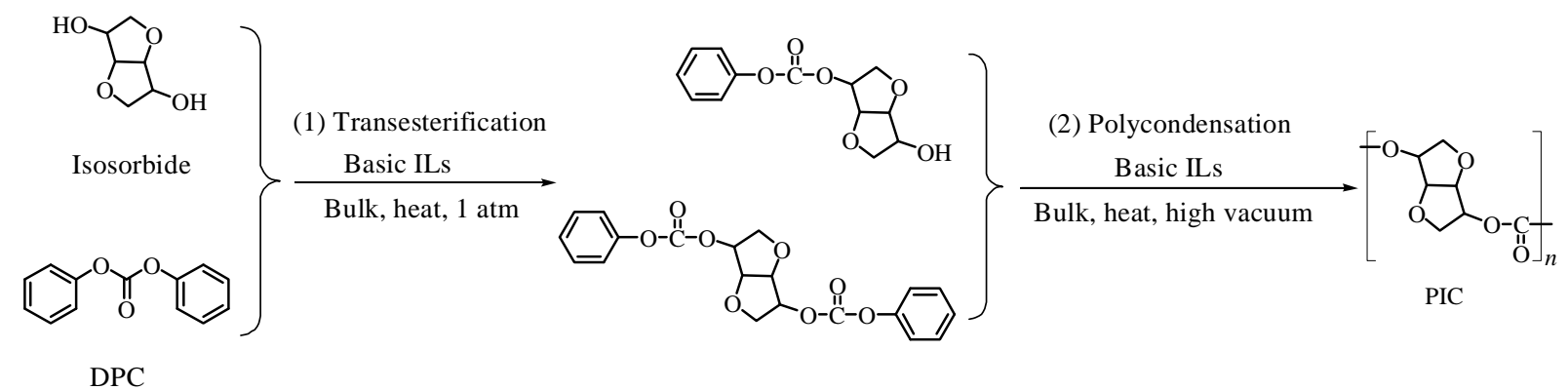

DPC 

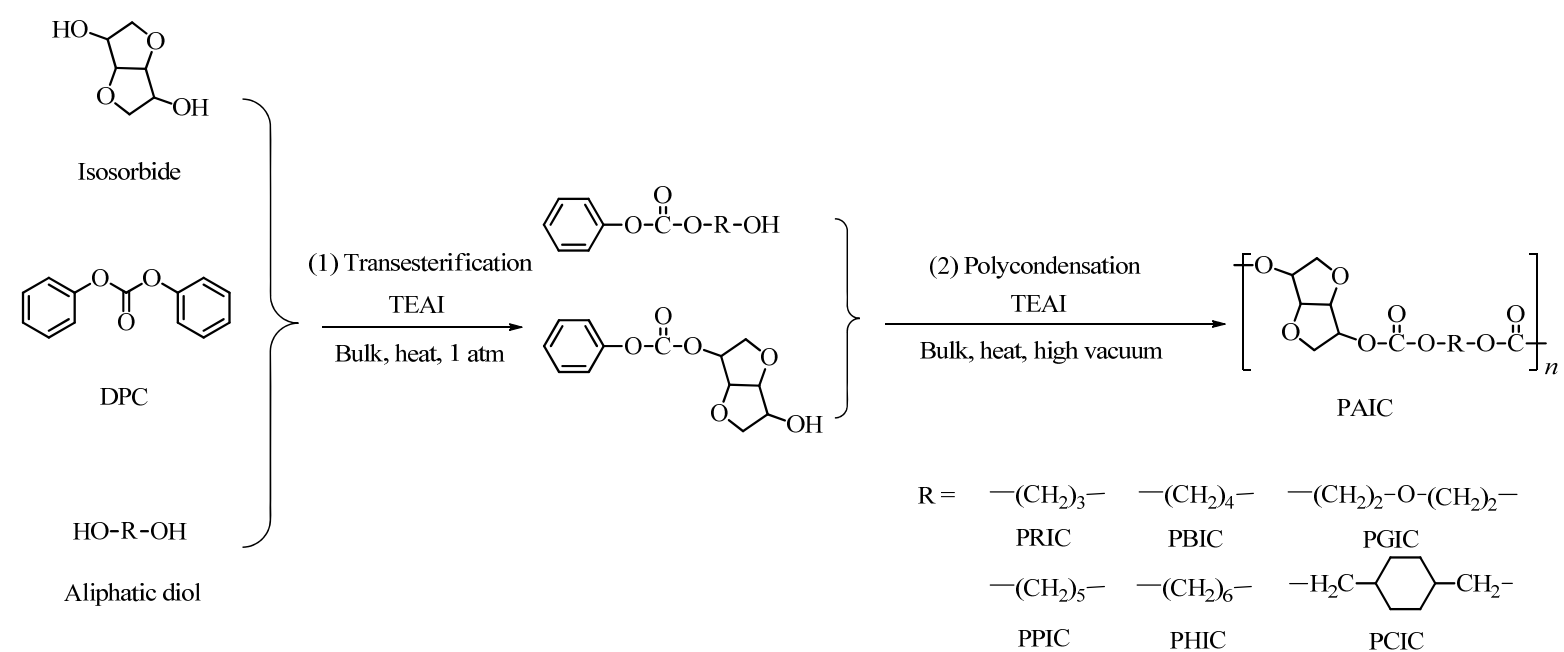

Scheme 3. One-pot melt polycondensation of DPC with isosorbide and aliphatic diols.

dure (sample PCIC) was carried out as follows. In the transesterification stage, isosorbide $(2.19 \mathrm{~g}, 0.015 \mathrm{~mol}), 1,4$-cyclohexanedimethanol (2.16 g, $0.015 \mathrm{~mol})$ and DPC (6.43 g, 0.03 mol) were transferred into a $250 \mathrm{~mL}$ three-necked round-bottom flask. The temperature was gradually increased to $98^{\circ} \mathrm{C}$ and the catalyst TEAI $\left(0.003 \mathrm{~g}, 1.5 \times 10^{-5} \mathrm{~mol}\right)$ was injected into the flask followed by continuous stirring for $5 \mathrm{~h}$. The remaining synthesis steps were the same as those applied in the synthesis of the homopolycarbonates. As a result, a PAIC incorporating 1,4-cyclohexanedimethanol was obtained, referred to herein as PCIC. PCIC, ${ }^{1} \mathrm{H}$ NMR (600 MHz, $\mathrm{CDCl}_{3}, 298$ K): 0.99-1.08 (br, 2.6H), 1.37-1.50 (br, 2.6H), 1.50-1.72 (br, $3.9 \mathrm{H}), 1.77-1.91$, (br, 3.9H), 3.88-4.13 (br, 9.2H), 4.52-4.60 (br, 1H), 4.88 (br, 1H), 5.06-5.12 (br, 2H); ${ }^{13} \mathrm{C}\left\{{ }^{1} \mathrm{H}\right\}$ NMR $(150$ $\left.\mathrm{MHz}, \mathrm{CDCl}_{3}, 298 \mathrm{~K}\right): 25.1,28.6,34.5,37.1,70.6,71.1,72.8,73.3$, $76.7,77.2,81.0,81.2,81.5,85.9,85.7,154.0,153.6,153.3,154.4$, $154.7,155.5$.

The synthetic method for PRIC was the same as that for PCIC, except that 1,3-propanediol (1.14 g, $0.015 \mathrm{~mol}$ ) was added. ${ }^{1} \mathrm{H}$ NMR (600 MHz, $\mathrm{CDCl}_{3}, 298 \mathrm{~K}$ ): 2.01-2.13 (br, 0.4H), 3.86-4.08 (br, 4H), 4.11-4.29 (br, 0.8H), 4.52-4.58 (br, 1H), $4.89(\mathrm{t}, 1 \mathrm{H}), 5.06-5.13(\mathrm{br}, 2 \mathrm{H}) .{ }^{13} \mathrm{C}\left\{{ }^{1} \mathrm{H}\right\} \mathrm{NMR}\left(150 \mathrm{MHz}, \mathrm{CDCl}_{3}\right.$, $298 \mathrm{~K}): 28.0,64.3,64.8,70.6,73.0,73.1,77.0,77.2,80.0,81.2$, $81.5,85.7,85.8,153.9,153.5,153.0,154.1,154.4,155.1$.

The synthetic method for PBIC was the same as that for PCIC, except that 1,4-butanediol (1.35 g, $0.015 \mathrm{~mol}$ ) was added. ${ }^{1} \mathrm{H}$ NMR (600 MHz, $\mathrm{CDCl}_{3}, 298 \mathrm{~K}$ ): 1.70-1.91 (br, 3.2H), 3.91-4.10 (br, 4H), 4.12-4.28 (br, 3.2H), 4.50-4.61 (br, 1H), $4.85(\mathrm{t}, 1 \mathrm{H}), 5.03-5.13(\mathrm{br}, 2 \mathrm{H}) .{ }^{13} \mathrm{C}\left\{{ }^{1} \mathrm{H}\right\} \mathrm{NMR}\left(150 \mathrm{MHz}, \mathrm{CDCl}_{3}\right.$, $298 \mathrm{~K}): 25.0,67.3,67.8,70.6,73.1,73.3,77.0,77.2,81.0,81.2$, 81.6, 85.8, 86.0, 153.9, 153.6, 153.0, 154.2, 154.6, 155.2.

The synthetic method for PPIC was the same as that for PCIC, except that 1,5-pentanediol (1.56 g, $0.015 \mathrm{~mol}$ ) was added. ${ }^{1} \mathrm{H}$ NMR (600 MHz, $\mathrm{CDCl}_{3}, 298 \mathrm{~K}$ ): 1.40-1.50 (br, $\left.1 \mathrm{H}\right)$, 1.61-1.74 (br, 2H), 3.82-4.10 (br, 4H), 4.10-4.20 (br, 2H), 4.46-4.56 (br, 1H), $4.86(\mathrm{t}, 1 \mathrm{H}), 5.01-5.12(\mathrm{br}, 2 \mathrm{H}) .{ }^{13} \mathrm{C}\left\{{ }^{1} \mathrm{H}\right\}$ $\mathrm{NMR}\left(150 \mathrm{MHz}, \mathrm{CDCl}_{3}, 298 \mathrm{~K}\right): 22.0,28.4,67.7,68.2,70.6,73.1$, 73.3, 76.7, 77.3, 81.0, 81.2, 81.7, 85.8, 86.0, 153.9, 153.6, 153.0, $154.3,154.6,155.3$.
The synthetic method for PHIC was the same as that for PCIC, except that 1,6-hexanediol (1.77 g, $0.015 \mathrm{~mol})$ was added. ${ }_{1}^{1} \mathrm{H}$ NMR (600 MHz, $\mathrm{CDCl}_{3}, 298 \mathrm{~K}$ ): 1.31-1.47 (br, 1.6H), 1.60-1.72 (br, 1.6H), 3.82-4.08 (br, 4H), 4.08-4.17 (br, 1.6H), 4.47-4.56 (br, $1 \mathrm{H}), 4.86(\mathrm{t}, 1 \mathrm{H}), 5.01-5.11(\mathrm{br}, 2 \mathrm{H}) .{ }^{13} \mathrm{C}\left\{{ }^{1} \mathrm{H}\right\}$ NMR (150 MHz, CDCl 3,298 K): 25.3, 28.5, 67.8, 68.4, 70.6, 73.1, 73.3, 76.6, 77.3, 81.2, 81.6, 81.7, 85.8, 86.0, 153.9, 153.6, 153.0, 154.3, 154.6, 155.3 .

The synthetic method for PGIC was the same as that for PCIC, except that diethylene glycol $(1.59 \mathrm{~g}, 0.015 \mathrm{~mol})$ was added. ${ }^{1} \mathrm{H}$ NMR (600 MHz, $\mathrm{CDCl}_{3}, 298 \mathrm{~K}$ ): 3.64-3.76 (br, 4.4H), 3.92-4.08 (br, 4H), 4.21-4.34 (br, 4.4H), 4.46-4.55 (br, 1H), $4.85(\mathrm{t}, 1 \mathrm{H}), 5.00-5.11(\mathrm{br}, 2 \mathrm{H}) .{ }^{13} \mathrm{C}\left\{{ }^{1} \mathrm{H}\right\}$ NMR $\left(150 \mathrm{MHz}, \mathrm{CDCl}_{3}\right.$, $298 \mathrm{~K}): 66.8,67.1,67.2,67.4,70.5,73.0,73.2,76.1,77.3,80.9$, 81.1, 81.4, 85.8, 85.9, 154.2, 153.6, 153.0, 154.2, 154.5, 155.1 .

\section{Results and discussion}

\subsection{Synthesis and characterization of catalysts}

Six quaternary ammonium IL catalysts were synthesized and the structures of these compounds were determined by ${ }^{1} \mathrm{H}$ NMR. The resulting spectra agreed with the anticipated chemical structures and with data from a prior study. The thermal stability of each of the synthesized ILs was also tested using TGA (Fig. 1), and each of these compounds exhibited excellent thermal stability.

\subsection{Effect of catalysts}

As noted, the polymerization of isosorbide and DPC was performed in the presence of a series of ILs based on quaternary ammonium cations combined with $\mathrm{Im}^{-}$(imidazolate), $\mathrm{Tr}^{-}$ (1,2,4-triazolate), $\quad \mathrm{OH}^{-}, \quad \mathrm{OAc}^{-}, \quad \mathrm{PhCOO}^{-}, \quad \mathrm{N}(\mathrm{CN})_{2}^{-}$or $\mathrm{CH}_{3} \mathrm{CHOHCOO}^{-}$anions (Table 1). The effects of these cations and anions on the catalytic activity were investigated by comparing the $M_{\mathrm{w}}$ values of the resulting PIC. In the case of the ammonium-based ILs, the catalytic activity of the anions decreased in the order: $\mathrm{Im}^{-}>\mathrm{OH}^{-}>\mathrm{Tr}^{-}>\mathrm{PhCOO}^{-}>\mathrm{N}(\mathrm{CN})_{2}^{-}, \mathrm{OAc}^{-}$, 


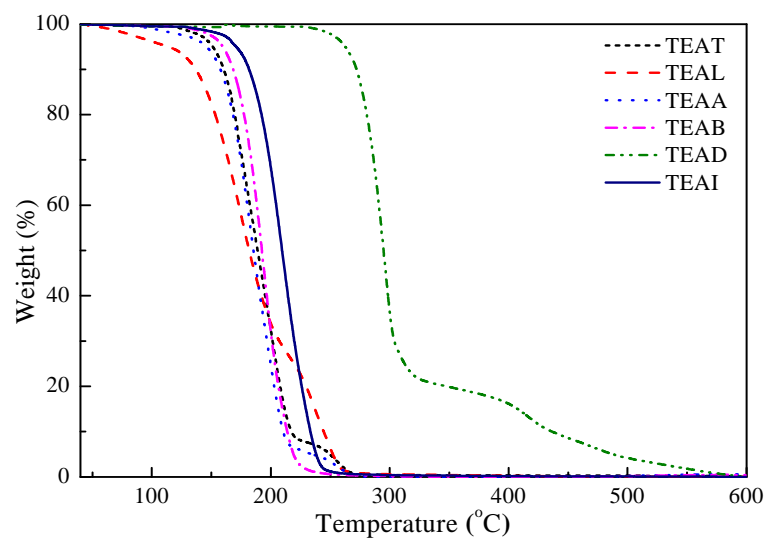

Fig. 1. TGA traces of the quaternary ammonium ILs.

$\mathrm{CH}_{3} \mathrm{CHOHCOO}^{-}$. These results imply that the basicity of the anion (with the exception of $\mathrm{Im}^{-}$, Table 2 ) is an important factor in determining the catalytic activity of the IL. However, although $\mathrm{Im}^{-}$is a weaker base than $\mathrm{OH}^{-}$, the catalytic activity of its IL was greater (Table 1 and Table 2). The weakly nucleophilic anions, including $\mathrm{N}(\mathrm{CN})_{2}{ }^{-}, \mathrm{OAc}^{-}$and $\mathrm{CH}_{3} \mathrm{CHOHCOO}^{-}$, also resulted in lower activities for this melt polycondensation reaction (PIC-6, 9 and 10, Table 1). In the case of the $\mathrm{OH}^{-}$anion, the (Et) ${ }_{4} \mathrm{~N}^{+}$cation produced a higher catalytic activity than the other cations (Table 1, PIC-1-4). Among these catalysts, TEAI, TEAH and TPAH showed the highest catalytic activities. Similar isosorbide conversions were achieved using all three of these catalysts, but the PIC-3 had a higher PDI. As well, even though the PDI values of the PIC- 2 and PIC-5 were almost the same, the $M_{\mathrm{w}}$ of the PIC- 5 was higher, and so we selected TEAI as the best catalyst. The data in Table 1 also demonstrate that the isosorbide conversion ranged from $74 \%$ to $96 \%$, which can be attributed to the evaporation of some of the isosorbide during the reaction process, in keeping with previous reports in the literature [49]. Therefore, we propose that the catalytic activity depends on both the basicity of the catalyst and the coordinating strength of the anion in the IL [50].

\subsection{Effects of other reaction parameters}

As can be seen from Fig. 2(a), the catalyst-to-isosorbide ratio had a pronounced effect on the reaction as it was varied from $1 \times 10^{-4}$ to $1 \times 10^{-3}$. The $M_{\mathrm{w}}$ values increased significantly,
Table 2

$\mathrm{pH}$ values of the catalysts.

\begin{tabular}{lccr}
\hline Catalyst & $\mathrm{pH}^{\mathrm{a}}$ & Catalyst & $\mathrm{pH}^{\mathrm{a}}$ \\
\hline TMAH & 13.01 & TEAD & 7.39 \\
TEAH & 13.00 & TEAT & 10.48 \\
TPAH & 12.99 & TEAB & 7.98 \\
TBAH & 12.90 & TEAL & 7.54 \\
TEAI & 12.31 & TEAA & 6.62 \\
\hline
\end{tabular}

a Determined by $\mathrm{pH}$ meter at $25^{\circ} \mathrm{C}$ at a catalyst concentration of 0.1 $\mathrm{mol} / \mathrm{L}$.

from 14800 to $23600 \mathrm{~g} / \mathrm{mol}$, as $n$ (catalyst): $n$ (isosorbide) was increased from $1 \times 10^{-4}$ to $5 \times 10^{-4}$, and then declined over the range of $5 \times 10^{-4}$ to $1 \times 10^{-3}$. The conversion values also rose significantly, from $84 \%$ to $93 \%$, as the $n$ (catalyst): $n$ (isosorbide) ratio was increased from $1 \times 10^{-4}$ to $5 \times 10^{-4}$, although there were no further obvious variations in the $5 \times 10^{-4}$ to $1 \times 10^{-3}$ range. A low $n$ (catalyst): $n$ (isosorbide), such as $1 \times 10^{-4}$, resulted in difficulty in obtaining the desired polymerization activity, such that the $M_{\mathrm{w}}$ and isosorbide conversion were lower. However, ratios above $1 \times 10^{-3}$ gave a brownish PIC. These results demonstrated that the optimum catalyst amount for the PIC synthesis was $5 \times 10^{-4}$.

The effects of polycondensation time on the $M_{\mathrm{w}}$ and isosorbide conversion were investigated at $230{ }^{\circ} \mathrm{C}$ and a catalyst-to-isosorbide ratio of $5 \times 10^{-4}$ (Fig. 2(b)). The $M_{\mathrm{w}}$ values increased significantly as the polycondensation time was prolonged from 3 to $5 \mathrm{~h}$, and then decreased over the range of 5 to $7 \mathrm{~h}$. The change in the isosorbide conversion was not significant between 3 and $7 \mathrm{~h}$ owing to the excellent thermal stability of the PIC. However, overly long time spans can lead to degradation of the PIC at high temperatures, such that a brownish product was obtained following $7 \mathrm{~h}$. These data indicate that the ideal polycondensation time for the PIC was $5 \mathrm{~h}$.

The dependence of $M_{\mathrm{w}}$ and isosorbide conversion on the polycondensation temperature were also investigated, at a catalyst-to-isosorbide ratio of $5 \times 10^{-4}$ over $5 \mathrm{~h}$ (Fig. 2(c)). The $M_{\mathrm{w}}$ values were found to increase gradually as the temperature was raised from 210 to $240{ }^{\circ} \mathrm{C}$, followed by a decline between 240 and $250{ }^{\circ} \mathrm{C}$. The change in the isosorbide conversion was insignificant from 210 to $250{ }^{\circ} \mathrm{C}$, again owing to the superior thermal stability of the PIC. Because the product is more viscous at low temperatures, elevated temperatures are necessary for the polycondensation, although they can promote unde-
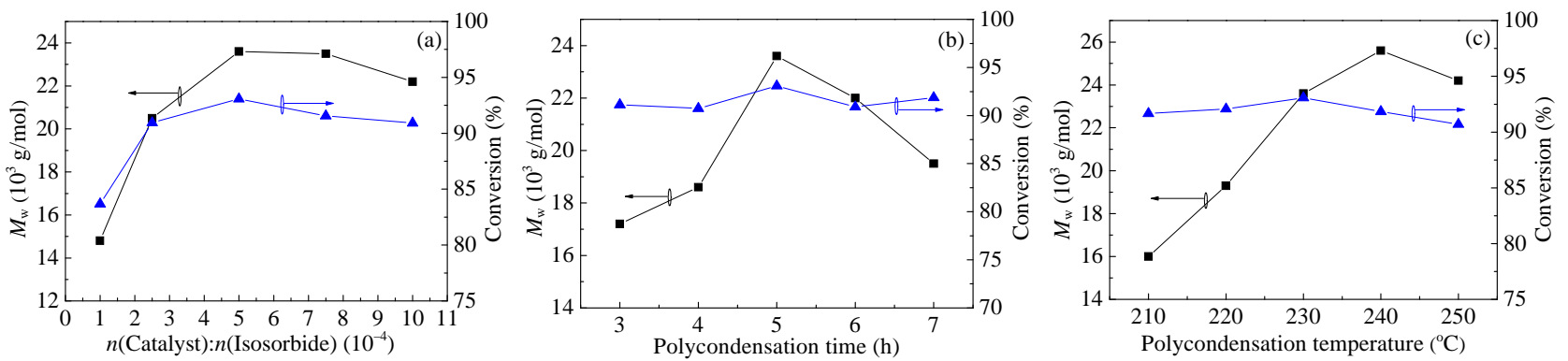

Fig. 2. Effect of the catalyst-to-isosorbide ratio (a), polycondensation time (b) and polycondensation temperature (c) on $M_{\mathrm{w}}$ and isosorbide conversion. 

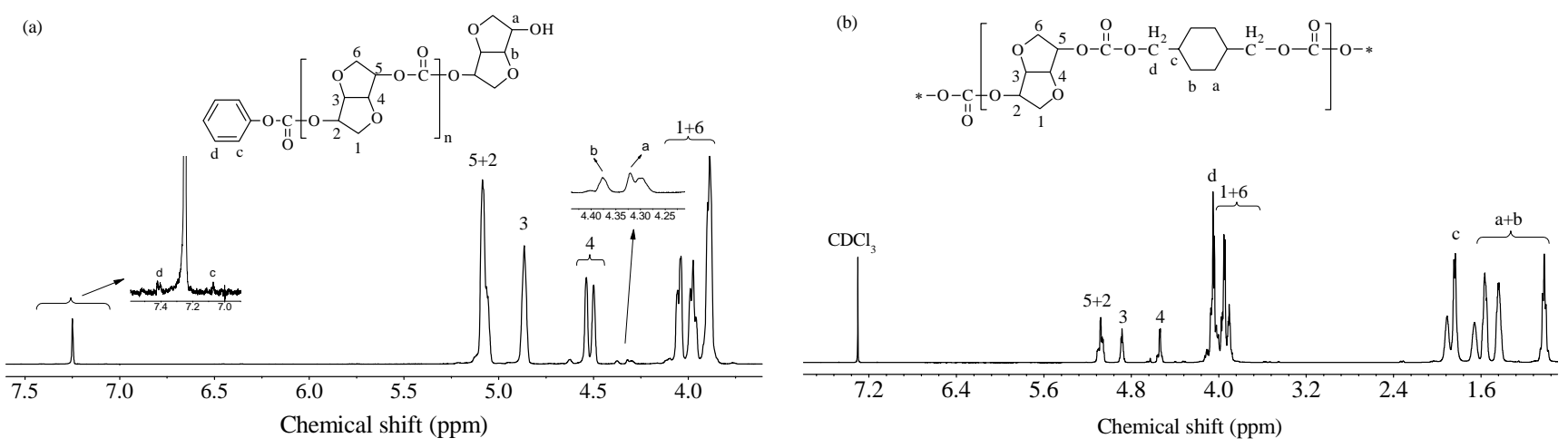

Fig. 3. ${ }^{1} \mathrm{H}$ NMR spectra of PIC-1 (a) and PCIC (b).

sired side reactions, resulting in a brown color and crosslinking. The results show that the optimum polycondensation temperature for the PIC was $240^{\circ} \mathrm{C}$.

\subsection{Synthesis and structure characterization of PIC and PAICS}

The chemical structures of the PIC-1 and PAICs specimens were determined by ${ }^{1} \mathrm{H}$ NMR spectroscopy, and the ${ }^{1} \mathrm{H}$ NMR spectra of the PIC-1 and PCIC are presented in Fig. 3. In Fig. $3(\mathrm{a})$, the two multiplet signals between 4.28 and $4.40 \mathrm{ppm}$ are attributed to terminal isosorbide groups and the two singlets at 7.09 and 7.43 ppm are assigned to terminal phenyl carbonate groups. The PAICs compositions (Table 3) were determined based on the integration values for peaks resulting from the repeating units, and the calculated compositions were found to deviate from the feed ratios. It is therefore evident that the hydroxyl groups of the different monomers had varying levels of reactivity, with the diethylene glycol and 1,4-cyclohexanedimethanol being the most active.

The ${ }^{13} \mathrm{C}$ NMR spectrum of the PIC-1 is provided in Fig. 4. As isosorbide has two different hydroxyl groups (exo and endo), the spectrum displays three $\mathrm{C}=0$ signals with intensity ratios of $1: 2: 1$, attributed to the endo-endo, endo-exo, exo-endo and exo-exo linked carbonate groups. This random sequence was consistent with the PIC structure reported by Chatti et al. [26].

The microstructures of the PAIC samples were determined by ${ }^{13} \mathrm{C}$ NMR spectroscopy, and the assignments of signals are summarized in Fig. 5. As shown in Fig. 5(a), all the peaks ascribed to the PCIC repeating units were well resolved, especial-

Table 3

Results obtained from the copolycondensation of isosorbide and aliphatic diols.

\begin{tabular}{lcccc}
\hline Sample & Is/Diol & Conversion & \\
b $(\%)$ & $M_{\mathrm{w}}{ }^{\mathrm{c}}(\mathrm{g} / \mathrm{mol})$ & $M_{\mathrm{w}} / M_{\mathrm{n}}$ \\
\hline PHIC & $1 / 0.4$ & 82 & 43700 & 2.60 \\
PPIC & $1 / 0.5$ & 88 & 40400 & 2.32 \\
PBIC & $1 / 0.8$ & 87 & 70500 & 3.07 \\
PCIC & $1 / 1.3$ & 83 & 95300 & 2.87 \\
PGIC & $1 / 1.1$ & 89 & 112000 & 3.17 \\
PRIC & $1 / 0.2$ & 75 & 29000 & 3.47 \\
\hline
\end{tabular}

a Molar composition determined by ${ }^{1} \mathrm{H}$ NMR spectroscopy.

b Conversion of isosorbide and aliphatic diols to copolycarbonates.

c Determined by GPC in chloroform $(1.0 \mathrm{~mL} / \mathrm{min})$ at $30^{\circ} \mathrm{C}$, with polystyrene standards. ly the carbonyl carbons that are sensitive to sequence effects at the dyad level. The six different carbonyl carbon signals are denoted herein as AA, AIs (or IsA) and IsIs respectively, as shown in Fig. 5(b). The dyad contents were calculated by integration of the peaks included in these signals. Based on these values, the number-average sequence length $\left(L_{\mathrm{n}}\right)$ and the degree of randomness $(B)$ were calculated according to the following equations [51].

$$
\begin{gathered}
L_{\mathrm{nAC}}=\left(f_{\mathrm{AC} / \mathrm{IsC}}+2 f_{\mathrm{AC} / \mathrm{AC}}\right) / f_{\mathrm{AC} / \mathrm{IsC}} \\
L_{\mathrm{nIsC}}=\left(f_{\mathrm{AC} / \mathrm{IsC}}+2 f_{\mathrm{IsC} / \mathrm{IsC}}\right) / f_{\mathrm{AC} / \mathrm{IsC}} \\
B=1 / L_{\mathrm{nAC}}+1 / L_{\mathrm{nISC}}
\end{gathered}
$$

Here, $f_{\mathrm{AC} / \mathrm{AC}}, f_{\mathrm{AC} / \mathrm{IsC}}$ and $f_{\mathrm{IsC} / \mathrm{IsC}}$ represent the molar fractions of the dyads, calculated from the integral intensities of the carbonyl carbon signals from the AA, AIs (or IsA), and IsIs dyads, respectively, and $L_{\mathrm{nAC}}$ and $L_{\mathrm{nIsC}}$ are the number average sequence lengths of the aliphatic carbonate (AC) and isosorbide carbonate (IsC) units, respectively. The results are summarized in Table 4. As shown, all the $B$ values of the PAICs were different from one another, demonstrating that isosorbide had different levels of reactivity with the various aliphatic diols. Thus, the $\mathrm{AC}$ and IsC units exhibited statistically random distribution in each of the PAICs.

\subsection{Thermal properties}

The thermal properties of the PIC and PAIC specimens were evaluated by DSC and TGA, with the results shown in Table 5.
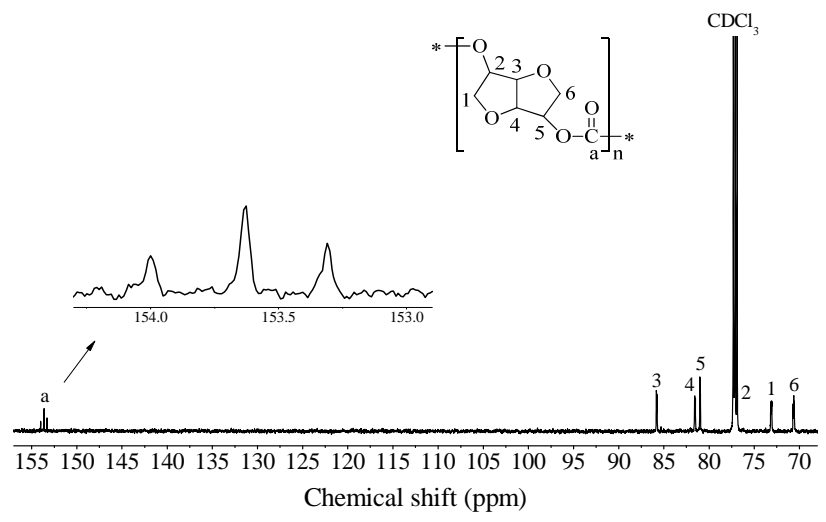

Fig. 4. ${ }^{13} \mathrm{C}$ NMR spectrum of PIC-1. 
(a)

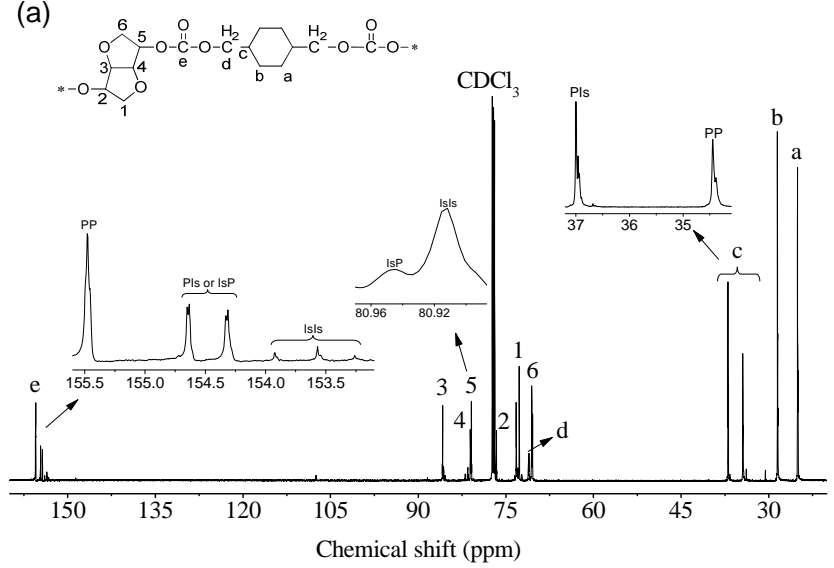

(b)

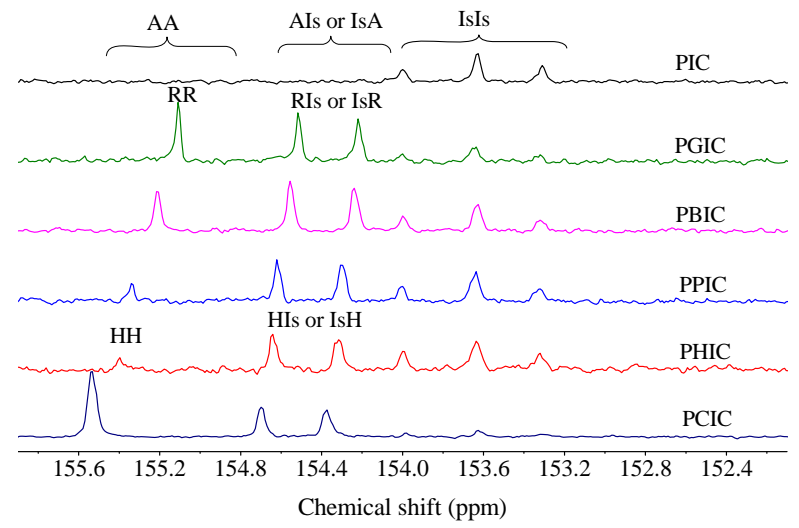

Fig. 5. (a) ${ }^{13} \mathrm{C}$ NMR spectrum of PCIC and (b) expanded spectra of the PAICs in the carbonyl carbon region.

All samples were found to be in an amorphous state. Fig. 6(a) presents the DSC traces of these samples. The PIC displayed a remarkably high $T_{\mathrm{g}}$ of $162^{\circ} \mathrm{C}$. This sample was amorphous as a result of the unsymmetrical carbonate linkages between repeat units, while its high $T_{\mathrm{g}}$ was due to the rigid structure of isosorbide. A single unique $T_{\mathrm{g}}$ was observed for each of the PAICs throughout the -100 to $200{ }^{\circ} \mathrm{C}$ range, and the $T_{\mathrm{g}}$ values ranged from 47 to $115^{\circ} \mathrm{C}$ depending on the structure of the comonomer. The $\mathrm{T}_{\mathrm{g}}$ of the linear diol PAICs were also observed to shift to lower temperatures with increasing methylene numbers in the linear aliphatic diol units. The PCIC displayed a higher $T_{\mathrm{g}}$ than the PAICs made with linear diols because of the rigid cyclohexane groups.

The TGA traces of PIC and PAICs are presented in Fig. 6(b). Each of these polymers displayed a single-step thermal decomposition process. Table 4 summarizes the $T_{\mathrm{d}}$ values of the samples at $5 \%$ weight loss $\left(T_{\mathrm{d}-5 \%}\right)$ and maximum degradation rate $\left(T_{\mathrm{d}-\mathrm{max}}\right)$. The PCIC, incorporating cyclohexane groups, displayed a higher $T_{\mathrm{d}-5 \%}$ and $T_{\mathrm{d} \text {-max }}$ compared to the PIC-1, while both the PIC-1 and PCIC showed greater thermal stability than the PAICs incorporating linear diols. The thermal stability of each of the latter samples was improved with increases in the quantity of methylene groups in the linear aliphatic diol units.

\subsection{A discussion of the reaction mechanism}

Based on published reports and the results of this work, a probable catalytic cycle was proposed and is depicted in

Table 4

The microstructural analyses of PAICs.

\begin{tabular}{lrrrrrr}
\hline \multirow{2}{*}{ PAICs } & \multicolumn{3}{c}{ Dyads $^{\text {a }}(\mathrm{mol} \%)$} & \multirow{2}{*}{$L_{\text {nAC }}$} & \multirow{2}{*}{$L_{\text {nIsC }}$} & \multirow{2}{*}{$B$} \\
\cline { 2 - 4 } & \multicolumn{1}{c}{ AA } & AIs/IsA & \multicolumn{1}{c}{ IsIs } & & & \\
\hline PHIC & 0.55 & 45.37 & 54.08 & 1.02 & 3.38 & 1.27 \\
PPIC & 8.20 & 51.52 & 40.28 & 1.32 & 2.56 & 1.15 \\
PBIC & 21.01 & 52.10 & 26.89 & 1.81 & 2.03 & 1.05 \\
PCIC & 51.28 & 42.56 & 6.15 & 3.41 & 1.29 & 1.07 \\
PGIC & 33.44 & 61.20 & 5.35 & 2.09 & 1.17 & 1.33 \\
PRIC & 4.76 & 23.60 & 71.65 & 1.40 & 7.07 & 0.85 \\
\hline
\end{tabular}

${ }^{a}$ Experimental values obtained from ${ }^{13} \mathrm{C}$ NMR signals.
Scheme 4, using a homopolycarbonate as an example. Initially, isosorbide is transitioned to an alkoxide anion by the action of the feed catalyst (TEAI). Simultaneously, the DPC is polarized by the tetraethylammonium cation and thus undergoes reaction more readily (steps 1 and 2). Subsequently, the anions generated in the previous step attack the polarized DPC, while the phenol is removed under vacuum at a high temperature (step 3). An intermediate is produced and the polymer chain continues to grow until the PIC is obtained (step 4). The polycondensation mechanism affording the copolycarbonates is similar. However, because the hydroxyl groups of the various aliphatic diols have different reactivities, irregularly ordered PAIC chains are eventually formed. The validity of this mechanism was also assessed based on FT-IR data.

It is evident from the resulting IR spectra (Fig. 7(a) and (b)) that the characteristic sharp absorbance of the hydroxyl groups of the isosorbide shift from 3370 to $3415 \mathrm{~cm}^{-1}$ after the addition of the TEAI. This result suggests the formation of $\mathrm{N}-\mathrm{H}$ bonds between the hydroxyl groups and the $\mathrm{Im}^{-}$. In addition, the peak due to the $\mathrm{C}=0$ bond on the DPC (Fig. 7(c) and (d)) shifts only from 1775 to $1771 \mathrm{~cm}^{-1}$ upon adding the TEAI, suggesting that the $(\mathrm{Et})_{4} \mathrm{~N}^{+}$cation has little effect on the $\mathrm{C}=0$ bond. However, it is important to note that the addition of the TEAI to the mixture of the DPC and isosorbide (Fig. 7(e)) does induce relatively large variations in the characteristic absorbances of the two raw materials. This result indicates that the isosorbide,

Table 5

Thermal properties of the PIC and PAICs.

\begin{tabular}{lccc}
\hline Sample & $T_{\mathrm{g}} \mathrm{a}\left({ }^{\circ} \mathrm{C}\right)$ & $T_{\mathrm{d}-5 \%}{ }^{\mathrm{b}}\left({ }^{\circ} \mathrm{C}\right)$ & $T_{\mathrm{d}-\max } \mathrm{b}\left({ }^{\circ} \mathrm{C}\right)$ \\
\hline PIC & 162 & 329 & 375 \\
PCIC & 115 & 332 & 373 \\
PRIC & 90 & 316 & 379 \\
PGIC & 80 & 328 & 374 \\
PBIC & 84 & 319 & 367 \\
PPIC & 50 & 322 & 369 \\
PHIC & 47 & 323 & 370 \\
\hline
\end{tabular}

a Determined by DSC measurements at a heating rate of $10^{\circ} \mathrm{C} / \mathrm{min}$ (second heating).

${ }^{\mathrm{b}} T_{\mathrm{d}-5 \%}$ and $T_{\mathrm{d}-\mathrm{max}}$ determined by TGA under $\mathrm{N}_{2}$ at a heating rate of 10 ${ }^{\circ} \mathrm{C} / \mathrm{min}$. 

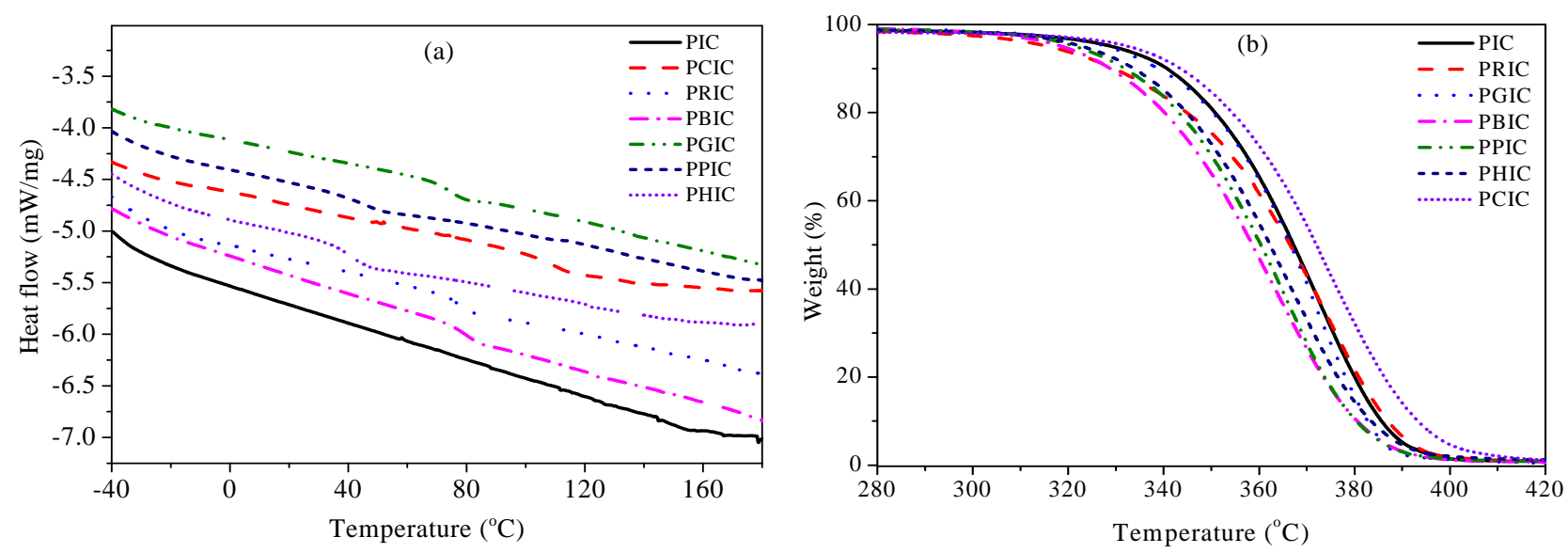

Fig. 6. DSC (a) and TGA (b) traces of the PIC and PAICs.

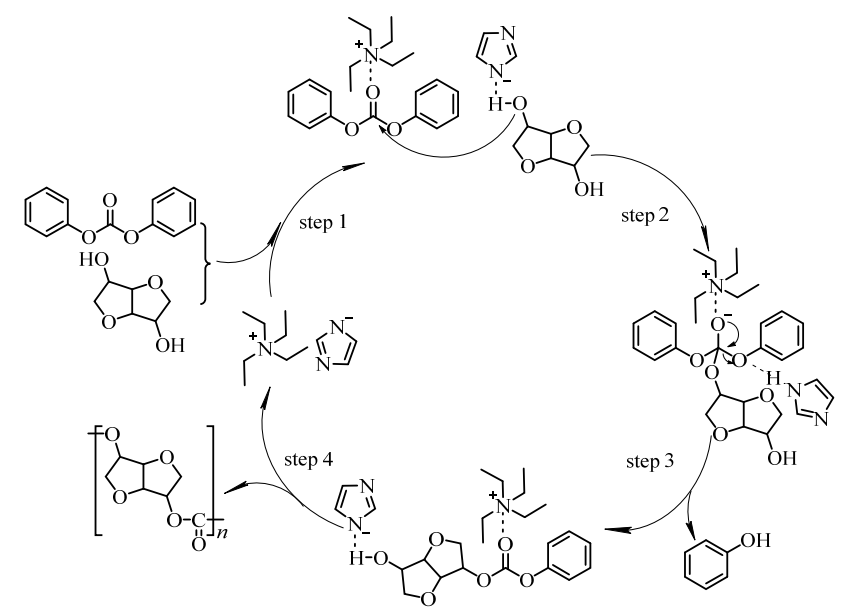

Scheme 4. Mechanism for the polymerization of PIC with TEAI as the catalyst.

which transitions to an alkoxide anion, attacks the polarized DPC. Based on the experimental results and this proposed mechanism, we believe that ILs that have significant nucleophilic and electrophilic properties are more favorable to the polymerization. However, overly nucleophilic or electrophilic properties will lead to reciprocal annihilation. Therefore, an optimal range of such properties is required to achieve superior performance for the desired reaction.

\section{Conclusions}

A series of quaternary ammonium ILs were successfully synthesized using different methods. Both homopolycarbonates and copolycarbonates were then obtained by melt polycondensation catalyzed by these ILs. Among these catalysts, TEAI showed the best catalytic activity, producing a polymer with a $M_{\mathrm{w}}$ of $25600 \mathrm{~g} / \mathrm{mol}$ and an isosorbide conversion of $92 \%$. The best copolycarbonate performance was achieved in the case of PCIC, which had a $M_{\mathrm{w}}$ of 95300 and a diol conversion of $83 \%$. The PAICs were found to have random microstructures, and their compositions showed significant varia-

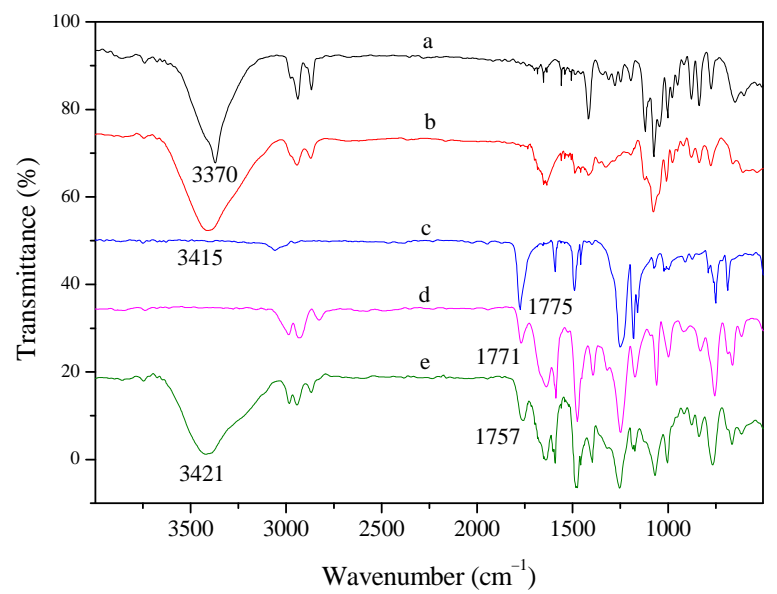

Fig. 7. IR spectra of isosorbide without TEAI (a), isosorbide with TEAI (b), DPC without TEAI (c), DPC with TEAI (d), and isosorbide and DPC with TEAI (e).

tions from the theoretical values predicted from the feed ratios. The PCIC sample showed the highest $T_{\mathrm{g}}$ and exhibited better thermal stability than the polymers made using linear diols. The data presented herein demonstrate that copolycarbonates such as PCIC have the potential to function as high-performance polymeric materials.

\section{References}

[1] G. H. Choi, D. Y. Hwang, D. H. Suh, Macromolecules, 2015, 48, 6839-6845.

[2] J. Kim, L. B. Dong, D. J. Kiserow, G. W. Roberts, Macromolecules, 2009, 42, 2472-2479.

[3] S. M. Gross, G. W. Roberts, D. J. Kiserow, J. M. DeSimone, Macromolecules, 2000, 33, 40-45.

[4] S. M. Gross, G. W. Roberts, D. J. Kiserow, J. M. DeSimone, Macromolecules, 2001, 34, 3916-3920.

[5] Y. S. Eo, H. W. Rhee, S. Shin, J. Ind. Eng. Chem., 2016, 37, 42-46.

[6] W. T. Tsai, J. Environ. Sci. Health, Part C, 2006, 24, 225-255.

[7] D. Dakshinamoorthy, F. Peruch, J. Polym. Sci. Part A: Polym. Chem., 2012, 50, 2161-2171.

[8] A. Gandini, Macromolecules, 2008, 41, 9491-9504. 


\section{Graphical Abstract}

Chin. J. Catal., 2017, 38: 908-917 doi: 10.1016/S1872-2067(17)62822-5

Synthesis of isosorbide-based polycarbonates via melt polycondensation catalyzed by quaternary ammonium ionic liquids

Wei Sun, Fei Xu, Weiguo Cheng, Jian Sun, Guoqing Ning *, Suojiang Zhang *

China University of Petroleum-Beijing; Institute of Process Engineering, Chinese Academy of Sciences

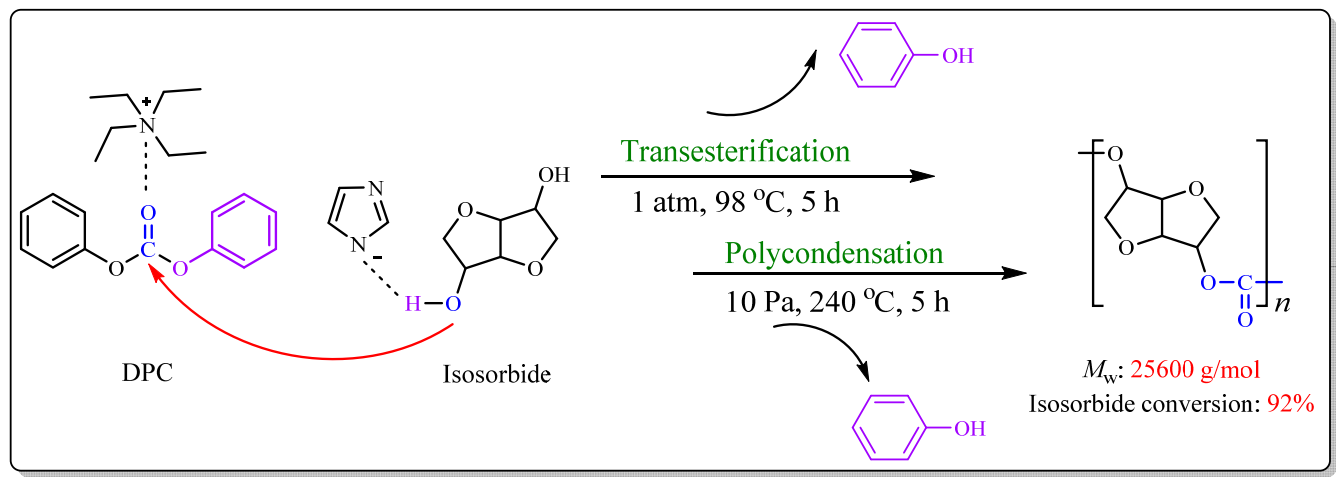

A series of quaternary ammonium ionic liquids were prepared and exhibited high catalytic activity for the synthesis of isosorbide-based polycarbonates via the melt polycondensation of diphenyl carbonate with isosorbide.

[9] A. Pascual, H. Sardon, A. Veloso, F. Ruiperez, D. Mecerreyes, ACS Macro Lett., 2014, 3, 849-853.

[10] H. R. Kricheldorf, J. Macromol. Sci. Rev. Macromol. Chem. Phys., 1997, 37, 599-631.

[11] F. Fenouillot, A. Rousseau, G. Colomines, R. Saint-Loup, J. P. Pascault, Prog. Polym. Sci., 2010,35, 578-622.

[12] L. Feng, W. Zhu, W. Zhou, C. Li, D. Zhang, Y. Xiao, L. Zheng, Polym. Chem., 2015, 6, 7470-7479.

[13] M. Yokoe, K. Aoi, M. Okada, J. Polym. Sci. Part A: Polym. Chem., 2003, 41, 2312-2321.

[14] H. R. Kricheldorf, S. Chatti, G. Schwarz, R. P. Krüger, J. Polym. Sci. Part A: Polym. Chem., 2003, 41, 3414-3424.

[15] L. Jasinska, C. E. Koning, J. Polym. Sci. Part A: Polym. Chem., 2010, 48, 5907-5915.

[16] R. Quintana, A. M. de Ilarduya, A. Alla, S. Muñoz-Guerra, J. Polym. Sci. Part A: Polym. Chem., 2011, 49, 2252-2260.

[17] C. H. Lee, H. Takagi, H. Okamoto, M. Kato, A. Usuki, J. Polym. Sci. Part A: Polym. Chem., 2009, 47, 6025-6031.

[18] R. Marín, A. Alla, A. Martínez de Ilarduya, S. Muñoz-Guerra, J. Appl. Polym. Sci., 2012, 123, 986-994.

[19] M. Beldi, R. Medimagh, S. Chatti, S. Marque, D. Prim, A. Loupy, F. Delolme, Eur. Polym. J., 2007, 43, 3415-3433.

[20] S. J. Sun, Y. C. Liao, T. C. Chang, J. Polym. Sci. Part A: Polym. Chem., 2000, 38, 1852-1860.

[21] M. Okada, M. Yokoe, K. Aoi, J. Appl. Polym. Sci, 2002, 86, 872-880.

[22] H. R. Kricheldorf, S. J. Sun, A. Gerken, T. C. Chang, Macromolecules, 1996, 29, 8077-8082.

[23] S. Chatti, H. R. Kricheldorf, G. Schwarz, J. Polym. Sci. Part A: Polym. Chem., 2006, 44, 3616-3628.

[24] S. J. Sun, G. Schwarz, H. R. Kricheldorf, T. C. Chang, J. Polym. Sci. Part A: Polym. Chem., 1999, 37, 1125-1133.

[25] B. A. J. Noordover, D. Haveman, R. Duchateau, R. A. T. M. van Benthem, C. E. Koning, J. Appl. Polym. Sci., 2011, 121, 1450-1463.

[26] S. Chatti, G. Schwarz, H. R. Kricheldorf, Macromolecules, 2006, 39, 9064-9070.
[27] T. Miyagawa, F. Sanda, T. Endo, Macromol. Chem. Phys., 2001, 202, 1602-1605.

[28] L. Feng, W. X. Zhu, C. C. Li, G. H. Guan, D. Zhang, Y. N. Xiao, L. C. Zheng, Polym. Chem., 2015, 6, 633-642.

[29] Q. Li, W. X. Zhu, C. C. Li, G. H. Guan, D. Zhang, Y. N. Xiao, L. C. Zheng, J. Polym. Sci. Part A: Polym. Chem., 2013, 51, 1387-1397.

[30] J. H. Park, J. Y. Jeon, J. J. Lee, Y. Jang, J. K. Varghese, B. Y. Lee, Macromolecules, 2013, 46, 3301-3308.

[31] Z. Q. Wang, X. G. Yang, J. G. Li, S. Y. Liu, G. Y. Wang, J. Mol. Catal. A., 2016, 424, 77-84.

[32] M. Yokoej, K. Keigo, M. Okada, J. Polym. Sci. Part A: Polym. Chem., 2003, 41, 2312-2321.

[33] O. Betiku, M. Jenni, K. Ludescher, E. Meierdierks, J. Lunt, J. Schroeder, Abstr. Pap. Am. Chem. Soc., 2007, 48, 802-803.

[34] W. Leitner, Nature, 2003, 423, 930-931.

[35] F. Jutz, J. M. Andanson, A. Baiker, Chem. Rev., 2011, 111, 322-353.

[36] Y. X. Yi, Y. Shen, J. K. Sun, B. Wang. F. Xu, R. C. Sun, Chin. J. Catal., 2014, 35, 757-762.

[37] Y. Liu, M. Li, Y. Lu, G. H. Gao, Q. Yang, M. Y. He, Catal. Commun., 2006, 7, 985-989.

[38] J. M. Xu, B. K. Liu, W. B. Wu, C. Qian, Q. Wu, X. F. Lin, J. Org. Chem., 2006, 71, 3991-3993.

[39] J. Q. Wang, J. Sun, C. Y. Shi, W. G. Cheng, X. P. Zhang, S. J. Zhang, Green Chem., 2011, 13, 3213.

[40] H. Y. Ju, M. D. Manju, D. W. Park, Y. Choe, S. W. Park, React. Kinet. Catal. Lett., 2007, 90, 3-9.

[41] R. D. Rogers, K. R. Seddon, Science, 2003, 302, 792-793.

[42] P. J. Scammells, J. L. Scott, R. D. Singer, Aust. J. Chem., 2005, 58, 155-169.

[43] T. Chang, X. R. Gao, L. Bian, X. Y. Fu, M. X. Yuan, H. W. Jing, Chin. J. Catal., 2015, 36, 408-413.

[44] D. R. MacFarlane, R. K. Seddon, Aust. J. Chem., 2007, 60, 3-5.

[45] J. F. Wang, J. Q. Luo, S. C. Feng, H. R. Li, Y. H.Wan, X. P. Zhang, Green Energy. Environ., 2016, 1, 43-61.

[46] J. J. Chen, C. Wang, B. Dong, W. G. Leng, J. Huang, R. L. Ge, Y. N. Gao, 
Chin. J. Catal., 2015, 36, 336-343.

[47] G. M. Dulcevscaia, V. C. Kravtsov, F. Z. Macaev, G. G. Duca, E. P. Stingachi, S. I. Pogrebnoi, V. V. Boldescu, S. F. Clapco, J. P. Tiurina, A. A. Deseatnic-Ciloci, J. Lipkowski, S. X. Liu, S. Decurtins, S. G. Baca, Polyhedron, 2013, 52, 106-114.

[48] D. R. MacFarlane, S. A. Forsyth, J. Golding, G. B. Deacon, Green
Chem., 2002, 4, 444-448.

[49] G. Flèche, M. Huchette, Starch/Stārke, 1986, 38, 26-30.

[50] L. Magna, J. Bildé, H. Olivier-Bourbigou, T. Robert, B. Gilbert, Oil. Gas. Sci. Technol., 2009, 64, 669-679.

[51] W. X. Zhu, W. Zhou, C. C. Li, Y. N. Xiao, D. Zhang, G. H. Guan, D. J. Wang, J. Macromol. Sci. Pure Appl. Chem., 2011, 48, 583-594.

\section{季铵类离子液体催化熔融缩聚反应合成异山梨醇基聚碳酸酯 \\ 孙 玮 ${ }^{\mathrm{a}, \mathrm{b}}$, 徐 菲, 成卫国 ${ }^{\mathrm{b}}$, 孙 剑 $^{\mathrm{b}}$, 宁国庆 ${ }^{\mathrm{a}, \# \text {, 张锁江 }}{ }^{\mathrm{b}, *}$ \\ a中国石油大学(北京)化学工程学院, 北京102249 \\ $\mathrm{b}^{\mathrm{b}}$ 中国科学院过程工程研究所多相复杂系统国家重点实验室, 离子液体清洁过程北京市重点实验室, 绿色过程与工程重点实验室, 北京100190}

摘要: 聚碳酸酯是一种性能优良的工程塑料, 具有优异的透明性、绝缘性及无毒性等优点. 目前实现大规模工业生产的是 双酚 $\mathrm{A}$ 型聚碳酸酯, 但是其生产原料双酚 $\mathrm{A}$ 具有毒性, 限制了其应用. 异山梨醇是一种生物基可再生单体, 具有无毒、手性和 刚性等特性, 是双酚 $\mathrm{A}$ 的理想替代品. 但是异山梨醇亲水性强, 且羟基的活性低, 导致碳酸二苯酯和异山梨醇通过熔融缩聚 反应合成异山梨醇基聚碳酸酯(PIC)困难, 因此选用合适的催化剂成为一个重要因素. 目前报道的效果较好的催化剂是无 机碱催化剂, 这类催化剂催化活性差, 容易引发副反应, 在产品中残留影响产品质量.

离子液体具有环境友好和阴阳离子可设计等优点, 是无机碱催化剂的良好替代品. 本文设计合成了六种季铵类的碱 性离子液体(四乙铵二氰胺盐、四乙铵咪唑盐、四乙铵乳酸盐、四乙铵-1,2,4-三氮唑盐、四乙铵苯甲酸盐和四乙铵乙酸盐), 用于催化熔融缩聚反应合成PIC. 用核磁共振表征了PIC的结构, 用凝胶色谱测定了PIC的分子量, 通过对比PIC的重均分子 量 $\left(M_{\mathrm{w}}\right)$ 和异山梨醇的转化率, 研究了离子液体阴离子对催化剂活性的影响. 发现催化活性不仅与离子液体的碱性强弱有 关, 还与离子液体阴离子的配位强度有关, 催化效果最好的离子液体为四乙铵咪唑盐(TEAI). 以TEAI为催化剂对合成PIC 的条件进行了优化, 得到的最优条件为: 催化剂与异山梨醇的摩尔比为 $5 \times 10^{-4}$, 缩聚时间为 $5 \mathrm{~h}$, 缩聚温度为 $240^{\circ} \mathrm{C}$. 合成 PIC的 $M_{\mathrm{w}}$ 为 $25600 \mathrm{~g} / \mathrm{mol}$, 异山梨醇的转化率为 $92 \%$.

由于均聚物PIC分子链刚性大, 导致PIC熔体粘度大, 不利于聚合, 为了降低PIC的刚性和提高分子量, 在分子链中引入 了柔性基团(脂肪族二醇)来合成共聚碳酸酯(PAIC). 以TEAI为催化剂, 异山梨醇和脂肪族二醇投料摩尔比为 $1: 1$, 通过熔融 缩聚反应合成了 PAICs. 利用 ${ }^{1} \mathrm{H}$ NMR 和 ${ }^{13} \mathrm{C}$ NMR 详细表征了 PAICs化学组成和微观结构, 发现不同脂肪族二醇的羟基活性 不同, 合成的PAICs 分子链中异山梨醇和脂肪族二醇的比例与投料比有所差异, 得到的共聚物为无规共聚物. 此外, 对 PAICs进行了凝胶色谱测试, 发现PAICs的 $M_{\mathrm{w}}$ 与PIC相比均有所提高. 通过差示扫描量热仪和热重分析仪对PIC和PAICs进 行了热稳定性测试. 结果表明, 对于不同直链二醇制备的PAICs, 随着二醇链中亚甲基数量的增加, 其玻璃化转变温度 $\left(T_{\mathrm{g}}\right)$ 逐渐降低, 但热稳定性逐渐提高; 而对于用 1,4 - 环已烷二甲醇合成的PCIC, 其 $T_{\mathrm{g}}$ 值和热稳定性明显高于直链脂肪族二醇共 聚物. 这些性能为共聚碳酸酯用作高性能聚合材料提供了可能性.

关键词: 季铵类离子液体催化剂; 异山梨醇; 聚碳酸酯; 熔融缩聚; 脂肪族二醇

收稿日期: 2017-02-27. 接受日期: 2017-03-22. 出版日期: 2017-05-05.

*通讯联系人. 电话/传真: (010)82627080; 电子信箱: sjzhang@home.ipe.ac.cn

\#通讯联系人. 传真: (010)69724721; 电子信箱: ngq@cup.edu.cn

基金来源：国家重点研发计划(2016YFB0600903); 国家自然科学基金(91434107, 21506226, 21476245); 中国科学院前沿科学重点 研究项目(QYZDY-SSW-JSC011).

本文的英文电子版由Elsevier出版社在ScienceDirect上出版(http://www.sciencedirect.com/science/journal/18722067). 